\title{
The last glacial termination on the eastern flank of the central Patagonian Andes ( $47^{\circ} \mathrm{S}$ )
}

\author{
William I. Henríquez ${ }^{1,2}$, Rodrigo Villa-Martínez ${ }^{3}$, Isabel Vilanova ${ }^{4}$, Ricardo De Pol-Holz ${ }^{3}$, and Patricio I. Moreno ${ }^{2}$ \\ ${ }^{1}$ Victoria University of Wellington, Wellington, New Zealand \\ ${ }^{2}$ Instituto de Ecología y Biodiversidad, Departamento de Ciencias Ecológicas, Universidad de Chile, \\ Casilla 653, Santiago, Chile \\ ${ }^{3}$ GAIA-Antártica, Universidad de Magallanes, Avda. Bulnes 01855, Punta Arenas, Chile \\ ${ }^{4}$ Museo Argentino de Ciencias Naturales Bernardino Rivadavia, Avda. Angel Gallardo 470, Buenos Aires, Argentina \\ Correspondence to: Patricio I. Moreno (pimoreno@uchile.cl)
}

Received: 2 September 2016 - Discussion started: 14 September 2016

Revised: 2 June 2017 - Accepted: 7 June 2017 - Published: 14 July 2017

\begin{abstract}
Few studies have examined in detail the sequence of events during the last glacial termination (T1) in the core sector of the Patagonian Ice Sheet (PIS), the largest ice mass in the Southern Hemisphere outside of Antarctica. Here we report results from Lago Edita $\left(47^{\circ} 8^{\prime} \mathrm{S}, 72^{\circ} 25^{\prime} \mathrm{W}\right.$, $570 \mathrm{~m}$ a.s.1.), a small closed-basin lake located in a valley overridden by eastward-flowing Andean glaciers during the Last Glacial Maximum (LGM). The Lago Edita record shows glaciolacustrine sedimentation until $19400 \mathrm{yr}$ BP, followed by organic sedimentation in a closed-basin lake and a mosaic of cold-resistant hygrophilous conifers and rainforest trees, along with alpine herbs between 19400 and $11000 \mathrm{yr}$ BP. Our data suggest that the PIS retreated at least $\sim 90 \mathrm{~km}$ from its LGM limit between $~ 21000$ and $19400 \mathrm{yr} \mathrm{BP}$ and that scattered, low-density populations of cold-resistant hygrophilous conifers, rainforest trees, high-Andean and steppe herbs thrived east of the Andes during the LGM and T1, implying high precipitation levels and southern westerly wind (SWW) influence at $47^{\circ} \mathrm{S}$. The conifer Podocarpus nubigena increased between 14500 and $13000 \mathrm{yr}$ BP, suggesting even stronger SWW influence during the Antarctic Cold Reversal, after which it declined and persisted until $11000 \mathrm{yr}$ BP. Large increases in arboreal pollen at $\sim 13000$ and $\sim 11000 \mathrm{yr} \mathrm{BP}$ led to the establishment of forests near Lago Edita between 10000 and $9000 \mathrm{yr} \mathrm{BP}$, suggesting a rise in the regional tree line along the eastern Andean slopes driven by warming pulses at $\sim 13000$ and $\sim 11000 \mathrm{yr} \mathrm{BP}$ and a subsequent decline in SWW influence at $\sim 11000 \mathrm{yr}$ BP. We propose that the PIS imposed a regional cooling signal along its eastern,
\end{abstract}

downwind margin through $\mathrm{T} 1$ that lasted until the separation of the northern and southern Patagonian ice fields along the Andes during the Younger Dryas period. We posit that the withdrawal of glacial and associated glaciolacustrine environments through $\mathrm{T} 1$ provided a route for the dispersal of hygrophilous trees and herbs from the eastern flank of the central Patagonian Andes, contributing to the afforestation of the western Andean slopes and pacific coasts of central Patagonia during T1.

\section{Introduction}

The Patagonian Ice Sheet (PIS) was the largest ice mass in the Southern Hemisphere outside of Antarctica during the last glacial maximum (LGM). Outlet lobes from the PIS flowed westward into the Pacific coast south of $43^{\circ} \mathrm{S}$ and eastward toward the extra-Andean Patagonian plains, blanketing a broad range of environments and climatic zones across and along the Andes. Land biota from formerly icefree sectors underwent local extinction or migrated toward the periphery of the advancing PIS during the last glaciation until its culmination during the LGM. The PIS then underwent rapid recession and thinning through the last glacial termination (termination $1=\mathrm{T} 1$ : between $\sim 18000$ and $11000 \mathrm{yr} \mathrm{BP}$ ) toward the Andes as illustrated by stratigraphic, geomorphic and radiocarbon-based chronologies from northwestern Patagonia $\left(39-43^{\circ} \mathrm{S}\right.$ ) (Denton et al., 1999; Moreno et al., 2015). These data, along with the Canal 

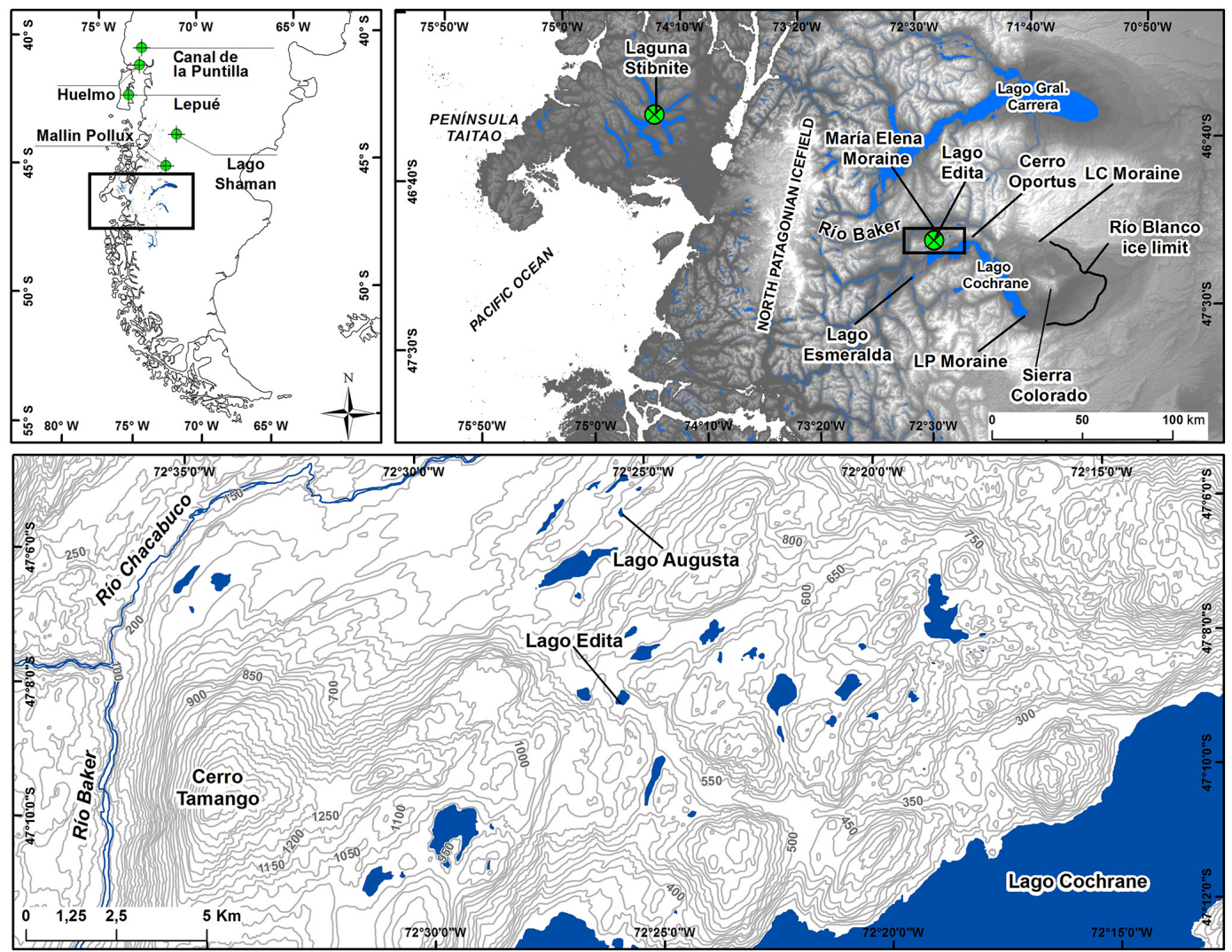

Figure 1. Sketch map of the study area showing the location of central-western Patagonia, the position of Valle Chacabuco relative to the Río Blanco, María Elena, Lago Columna (LC) and Lago Posada (LP) ice limits east Lago Cochrane, and the northern Patagonian ice field and the Taitao Peninsula to the west. We also included Sierra Colorado, Lago Esmeralda and Cerro Oportus for reference. The lower portion of the figure shows a detail on the Cerro Tamango area and the portion of Valle Chacabuco where Lago Edita and Lago Augusta are located. Also shown are palynological sites discussed in the main text (Canal de la Puntilla, Huelmo, Mallín Lago Shaman, Mallín Pollux, Lago Stibnite, Lago Augusta).

de la Puntilla-Huelmo pollen record $\left(\sim 41^{\circ} \mathrm{S}\right)$ (Moreno et al., 2015) (Fig. 1), indicate abandonment from the LGM margins in the lowlands at $17800 \mathrm{yr} \mathrm{BP}$, abrupt arboreal expansion and accelerated retreat that exposed Andean cirques located above $800 \mathrm{~m}$ a.s.l. within 1000 years or less in response to abrupt warming. Similarly, glaciers from Cordillera Darwin $\left(54-55^{\circ} \mathrm{S}\right)$, the southernmost ice field in South America, underwent rapid recession from their LGM moraines located in central and northern Tierra del Fuego prior to $17500 \mathrm{yr}$ BP and led to ice-free conditions by $16800 \mathrm{yr}$ BP near the modern ice fronts (Hall et al., 2013). Sea surface temperature records from the SE Pacific (Caniupán et al., 2011) are consistent with these terrestrial records; however, their timing, structure, magnitude and rate of change may be overprinted by the vicinity of former ice margins and shifts in marine reservoir ages (Caniupán et al., 2011; Siani et al., 2013).

In contrast, in the Andean sector of central-western Patagonia $\left(45-48^{\circ} \mathrm{S}\right)$ very few studies have been conducted about the timing of glacial advances near the end of the LGM or the structure and chronology of glacial retreat and climate changes during T1. Recent chronologies include cosmogenic radionuclides of terminal moraines of the Río Blanco, recessional moraines deposited by the Lago Cochrane ice lobe (LCIL) (Boex et al., 2013; Hein et al., 2010) (Fig. 1) and optically stimulated luminescence dating of glaciolacustrine beds associated with the glacial Lake Cochrane (GLC) $\left(47^{\circ} \mathrm{S}\right)$ (Glasser et al., 2016). These studies reported ages between 29000 and $19000 \mathrm{yr}$ BP for the final LGM advance and drainage of GLC toward the Pacific between 13000 and $8000 \mathrm{yr}$ BP caused by the breakup of the northern and southern Patagonian ice fields during the final stages of T1 (Turner et al., 2005). Palynological interpretations from the Lago Shaman $\left(44^{\circ} 26^{\prime} \mathrm{S}, 71^{\circ} 11^{\prime} \mathrm{W}, 919 \mathrm{~m}\right.$ a.s.l.) and Mallín Pollux $\left(45^{\circ} 41^{\prime} \mathrm{S}, 71^{\circ} 50^{\prime} \mathrm{W}, 640 \mathrm{~m}\right.$ a.s.l.) sites (de Porras et al., 2012; Markgraf et al., 2007), located east of the Andes (Fig. 1), indicate the predominance of cold and dry conditions during $\mathrm{T} 1$ and reduced southern westerly wind (SWW) influence. The validity and regional applicability of these stratigraphic, chronological and palynological interpretations, however, awaits replication with detailed strati- 
graphic and geomorphic data from sensitive sites constrained by precise chronologies.

Paleoclimate simulations (Bromwich et al., 2004, 2005) and stratigraphic studies (Kaufman et al., 2004) in the periphery of the Laurentide Ice Sheet in North America have detected that large ice sheets exerted important impacts on the thermal structure and atmospheric circulation on regional, continental and zonal scales from the LGM to the early Holocene. This aspect has remained largely unexplored in the PIS region and might be a factor of importance for understanding the dynamics of the SWW and climatic and biogeographic heterogeneities through $\mathrm{T} 1$ on a regional scale. Progress in this field requires an understanding of the deglacial chronology of the PIS and a suite of sensitive paleoclimate sites across and along the residual ice masses through the last transition from extreme glacial to extreme interglacial conditions.

In this study we report high-resolution pollen and macroscopic charcoal records from sediment cores we collected from Lago Edita $\left(47^{\circ} 8^{\prime} \mathrm{S}, 72^{\circ} 25^{\prime} \mathrm{W}, \sim 570 \mathrm{~m}\right.$ a.s.l. $)$, a medium-sized closed-basin lake (radius $\sim 250 \mathrm{~m}$ ) located in Valle Chacabuco $\sim 16 \mathrm{~km}$ northeast of the Cochrane township, east of the central Patagonian Andes (Fig. 1). The relevant source area for pollen from lakes of this size is about $600-800 \mathrm{~m}$ from the lake's edge, according to numerical simulations using patchy vegetation landscapes (Sugita, 1994). Stratigraphic and chronological results from Valle Chacabuco are important for elucidating the timing and rates of deglaciation in this core region of the PIS because this valley is located approximately $90 \mathrm{~km}$ upstream from the LGM moraines deposited by LCIL east of Lago Cochrane relative to the modern ice fronts, and its elevation spans the highest levels of GLC during T1. The Lago Edita data allow the assessment of vegetation and fire-regime and climate changes during the last global transition from extreme glacial to extreme interglacial conditions in central-western Patagonia. The aim of this paper is to contribute to (1) the development of a recessional chronology of the LCIL and (2) regressive phases of GLC, (3) document the composition and geographic shifts of the glacial and deglacial vegetation, (4) understand the tempo and mode of vegetation and climate changes during $\mathrm{T} 1$ and the early Holocene, (5) constrain the regional climatic influence of the PIS during T1 in terrestrial environments, and (6) improve our understanding of the biogeography of the region, including the identification of possible dispersal routes of tree taxa characteristic of modern evergreen forests in central-western Patagonia during T1.

\section{Study area}

Central Chilean Patagonia, i.e., the Aysén region $\left(43^{\circ} 45^{\prime}-\right.$ $47^{\circ} 45^{\prime} \mathrm{S}$ ), includes numerous channels, fjords, islands and archipelagos along the Pacific side, attesting to tectonic subsidence of Cordillera de la Costa and intense glacial erosion during the Quaternary. The central sector features an intricate relief associated with the Patagonian Andes with summits surpassing $3000 \mathrm{~m}$ a.s.1., deep valleys, lakes of glacial origin, and active volcanoes such as Hudson, Macá, Cay, Mentolat and Melimoyu (Stern, 2004). The Andes harbors numerous glaciers and the northern Patagonian ice field (Fig. 1), which acted as the source for multiple outlet glacier lobes that coalesced with glaciers from the southern Patagonian ice field to form the PIS during Quaternary glaciations, that blocked the drainage toward the Pacific, funneling large volumes of glacial meltwater toward the Atlantic (Turner et al., 2005). Farther to the east the landscape transitions into the back-arc extra-Andean plains and plateaus.

Patagonia is ideal for studying the paleoclimate evolution of the southern midlatitudes, including past changes in the SWW, because it is the sole continental landmass that intersects the low and mid-elevation zonal atmospheric flow south of $47^{\circ} \mathrm{S}$. Orographic rains associated with storms embedded in the SWW enhance local precipitation caused by the ascent of moisture-laden air masses along the western Andean slopes, giving way to subsidence and acceleration of moisture-deprived winds along the eastern Andean slopes (Garreaud et al., 2013). This process accounts for a steep precipitation gradient across the Andes, illustrated by the annual precipitation measured in the coastal township of Puerto Aysén $\left(2414 \mathrm{~mm}_{\text {year }}{ }^{-1}\right.$ ) and the inland Balmaceda (555 $\mathrm{mm} \mathrm{year}^{-1}$ ) (http://explorador.cr2.cl/), localities separated by $\sim 80 \mathrm{~km}$ across the west to east axis of the Andes. The town of Cochrane, located $\sim 15 \mathrm{~km}$ south of our study site features annual precipitation of $680 \mathrm{~mm} \mathrm{year}^{-1}$ and a mean annual temperature of $7.8^{\circ} \mathrm{C}$ (Fig. 1).

Weather station and reanalysis data along western Patagonia show positive correlations between zonal wind speed and local precipitation, a relationship that extends to sectors adjacent to the eastern slopes of the Andes (Garreaud et al., 2013; Moreno et al., 2014). Therefore, changes in local precipitation in the Aysén region are good diagnostics for atmospheric circulation changes associated with the frequency and intensity of storms embedded in the SWW over a large portion of the southeast Pacific. This relationship can be applied to paleoclimate records from central Chilean Patagonia for inferring the behavior of the SWW on the basis of past changes in precipitation or hydrologic balance.

The steep precipitation gradient, in conjunction with adiabatic cooling and enhanced continentality toward the east, influences the distribution and composition of the vegetation, inducing altitudinal, latitudinal and longitudinal zonation of plant communities throughout the Patagonian Andes. Physiognomic and floristic studies (Gajardo, 1994; Luebert and Pliscoff, 2006; Pisano, 1997; Schmithüsen, 1956) have recognized five units or communities, which we characterize succinctly in the following sentences:

- Magellanic moorland is a unit that occurs in maritime sectors with high precipitation (3000-4000 $\mathrm{mm} \mathrm{year}^{-1}$ 
and low seasonality) along the islands, fjords and channels. It is dominated by cushion-forming plants such as Donatia fascicularis, Astelia pumila and Tetroncium magallanicum. Also present are the hygrophilous coldresistant trees Nothofagus betuloides and the conifers Pilgerodendron uviferum, Lepidothamnus fonkii and Podocarpus nubigena.

- Evergreen rainforest is present in humid, temperate $\left(1500-3000 \mathrm{~mm}_{\text {year }}{ }^{-1} ;<600 \mathrm{~m}\right.$ a.s.l.) sectors of Aysén. This unit is characterized by the trees Nothofagus nitida, N. betuloides, Drimys winteri and P. nubigena, along with $P$. uviferum in waterlogged environments.

- Winter deciduous forests are located in cooler and/or drier sectors with higher seasonality (400$1000 \mathrm{~mm}$ year $^{-1} ; 500-1180 \mathrm{~m}$ a.s.l.). The dominant tree is Nothofagus pumilio, which intermingles with $N$. betuloides at western sites and the Patagonian steppe eastward. In the latter $N$. pumilio forms monospecific stands and presents a species-poor understory. A study of the spatial and temporal variation in $N$. pumilio growth at the tree line along its latitudinal range $\left(35^{\circ} 40^{\prime}-55^{\circ} \mathrm{S}\right)$ in the Chilean Andes (Lara et al., 2005) showed that temperature has a spatially larger control on tree growth than precipitation and that this influence is particularly significant in the temperate Andes $\left(>40^{\circ} \mathrm{S}\right)$. These results suggest that low temperatures are the main limiting factor for the occurrence of woodlands and forests at high elevations in the Andes, considering that precipitation increases with elevation at any given latitude (Lara et al., 2005). The modern tree line near Cochrane is dominated by $N$. pumilio and lies between 800 and $1180 \mathrm{~m}$ a.s.l.

- Patagonian steppe occurs in substantially drier $\left(<500 \mathrm{~mm}\right.$ year $\left.^{-1}\right)$ lowland areas with heightened continentality. This unit is dominated by herbs of the families Poaceae (Festuca, Deschampsia, Stipa, Hordeum, Rytidosperma, Bromus, Elymus) and Rubiaceae (Galium) and shrubs of the families Apiaceae (Mulinum), Rosaceae (Acaena), Fabaceae (Adesmia) and Rhamnaceae (Discaria).

- High-Andean desert occurs in the windswept montane environments above the tree line ( $>1000 \mathrm{~m}$ a.s.l.) under cold conditions, a high-precipitation regime and prolonged snow cover throughout the year. This vegetation unit is represented by herbs of the families Poaceae (Poa, Festuca), Asteraceae (Nassauvia, Senecio, Perezia), Berberidaceae (Berberis), Brassicaceae (Cardamine), Santalaceae (Nanodea), Rubiaceae (Oreopolus) Apiaceae (Bolax) and Ericaceae (Gaultheria, Empetrum), along with Gunnera magellanica and Valeriana, with occasional patches of Nothofagus antarctica.

\section{Materials and methods}

We collected overlapping sediment cores over the deepest sector of Lago Edita ( $8 \mathrm{~m}$ water depth) from an anchored coring rig equipped with $10 \mathrm{~cm}$ diameter aluminum casing tube, using a $5 \mathrm{~cm}$ diameter Wright piston corer and a $7.5 \mathrm{~cm}$ diameter sediment-water interface piston corer with a transparent plastic chamber. We characterized the stratigraphy through visual descriptions, digital $\mathrm{X}$ radiographs to identify stratigraphic structures and loss on ignition to quantify the amount of each organic, carbonate and siliciclastic component in the sediments (Heiri et al., 2001).

The chronology of the record is constrained by accelerator mass spectrometry (AMS) radiocarbon dates on bulk sediment and chronostratigraphic correlation of the $\mathrm{H} 1$ tephra from Mount Hudson (Stern et al., 2016). The radiocarbon dates were calibrated to calendar years before present (yr BP) using the CALIB 7.0 program. We developed a Bayesian age model using the Bacon package for R (Blaauw and Christen, 2011) to assign interpolated ages and confidence intervals for each level analyzed.

We processed and analyzed continuous and contiguous sediment samples $\left(2 \mathrm{~cm}^{3}\right)$ for pollen and fossil charcoal. The samples were processed using a standard procedure that includes $10 \% \mathrm{KOH}$, sieving with a $120 \mu \mathrm{m}$ mesh, $46 \%$ hydrofluoric acid (HF) and acetolysis (Faegri and Iversen, 1989). We counted between 200 and 300 pollen grains produced by trees, shrubs and herbs (terrestrial pollen) for each palynological sample and calculated the percent abundance of each terrestrial taxon relative to this sum. The percentage of aquatic plants was calculated in reference to the total pollen sum (terrestrial plus aquatic pollen) and the percentage of ferns from the total pollen and spores sum. Zonation of the pollen record was aided by a stratigraphically constrained cluster analysis on all terrestrial pollen taxa with $\geq 2 \%$, after recalculating sums and percentages.

We identified the palynomorphs based on a modern reference collection housed at the laboratory of Quaternary paleoecology of Universidad de Chile, along with published descriptions and keys (Heusser, 1971). In most cases the identification was done at family or genus level, in some cases at the species level (Podocarpus nubigena, Drimys winteri, Gunnera magellanica, Lycopodium magellanicum). The palynomorph Nothofagus dombeyi type includes the species $N$. antarctica, $N$. pumilio, $N$. betuloides and $N$. dombeyi. The morphotype Fitzroya/Pilgerodendron includes the cupressaceous conifers Fitzroya cupressoides and Pilgerodendron uviferum. We calculated running means of selected pollen taxa using a triangular weighing function of values along seven adjacent levels.

We tallied microscopic $(<120 \mu \mathrm{m})$ and macroscopic $(>106 \mu \mathrm{m})$ charcoal particles to document regional and local fire events, respectively. Microscopic particles were counted from each pollen slide, while macroscopic charcoal was counted from $2 \mathrm{~cm}^{3}$ sediment samples obtained from $1 \mathrm{~cm}$ 


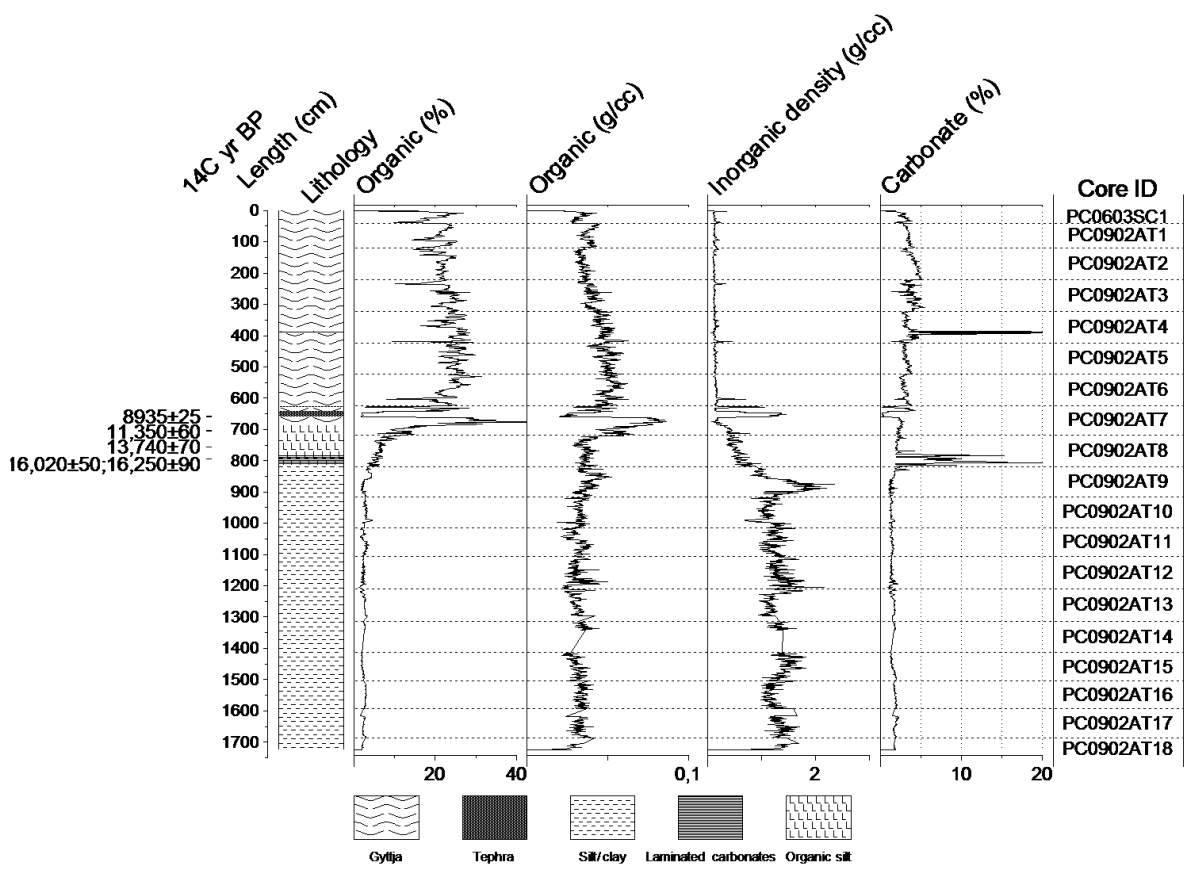

Figure 2. Stratigraphic column, radiocarbon dates and loss-on-ignition data from the Lago Edita record. The labels on the right indicate the identity and stratigraphic span (dashed horizontal lines) of each core segment.

thick and continuous and contiguous sections. The samples were prepared using a standard procedure that involves deflocculation in $10 \% \mathrm{KOH}$ and careful sieving through 106 and $212 \mu \mathrm{m}$ diameter meshes to avoid rupture of individual particles, followed by visual inspection on a Zeiss KL 1500 LCD stereoscope at $10 \times$ magnification. These results were analyzed by a time series analysis to detect local fire events using the CharAnalysis software (Higuera et al., 2009), interpolating samples at regular time intervals based in the median time resolution of the record. We deconvoluted the CHAR signal into a peaks and background component using a lowess robust-to-outlier smoothing with a 100 -year window width. We calculated locally defined thresholds to identify statistically significant charcoal peaks or local fire events (99th percentile of a Gaussian distribution).

\section{Results}

The sediment stratigraphy (Fig. 2) reveals a basal unit of blue-grey mud between 1726 and $819 \mathrm{~cm}$, horizontally laminated for the most part, in some sectors massive and sandier with small amounts of granule and gravel immersed in a clayey matrix (segment PC0902AT9). These inorganic clays are overlain by organic silt between 819 and $678 \mathrm{~cm}$ and organic-rich lake mud (gyttja) in the topmost $678 \mathrm{~cm}$. We found laminated authigenic carbonates between 794-759 and $394-389 \mathrm{~cm}$ (range: 5-20\%); for the remainder of the record carbonate values are negligible or null $(<5 \%)$. The record includes two tephras between $630-628$ and $661-643 \mathrm{~cm}$, which exhibit sharp horizontal contacts with the over and underlying mud and, consequently, we interpret them as aerial fallout deposits from explosive events originating from Mount Hudson (H1 tephra) and from Volcán Mentolat (M1 tephra) based on geochemical data (Stern et al., 2016).

The radiocarbon results show an approximately linear increase in age with depth between 19000 and $9000 \mathrm{yr} \mathrm{BP}$ (Fig. 3), which, in conjunction with the sediment stratigraphy, suggests undisturbed in situ pelagic deposition of lake mud and tephras in the Lago Edita basin. This study focuses on the interval between 19000 and $9000 \mathrm{yr}$ BP (Fig. 2, Table 1) and consists of 155 contiguous palynological and macroscopic charcoal levels with a median time step of 65 years between analyzed samples.

\subsection{Pollen stratigraphy}

We divided the record in six zones based on conspicuous changes in the pollen stratigraphy and a stratigraphically constrained cluster analysis to facilitate its description and discussion (Fig. 4). The following section describes each pollen zone, indicating the stratigraphic and chronological range, and the mean abundance of major taxa in parentheses.

Zone Edita-1 (795-780 cm; $19000-18100 \mathrm{yr} \mathrm{BP)} \mathrm{is} \mathrm{co-}$ dominated by Poaceae (33\%) and Empetrum (32\%). This zone starts with a gradual increase in Empetrum, attaining its maximum abundance $(\sim 53 \%)$ at the end of this zone. Asteraceae subfamily Asteroideae (7\%), Acaena (4\%), Caryophyllaceae (3\%) and Cyperaceae (9\%) de- 


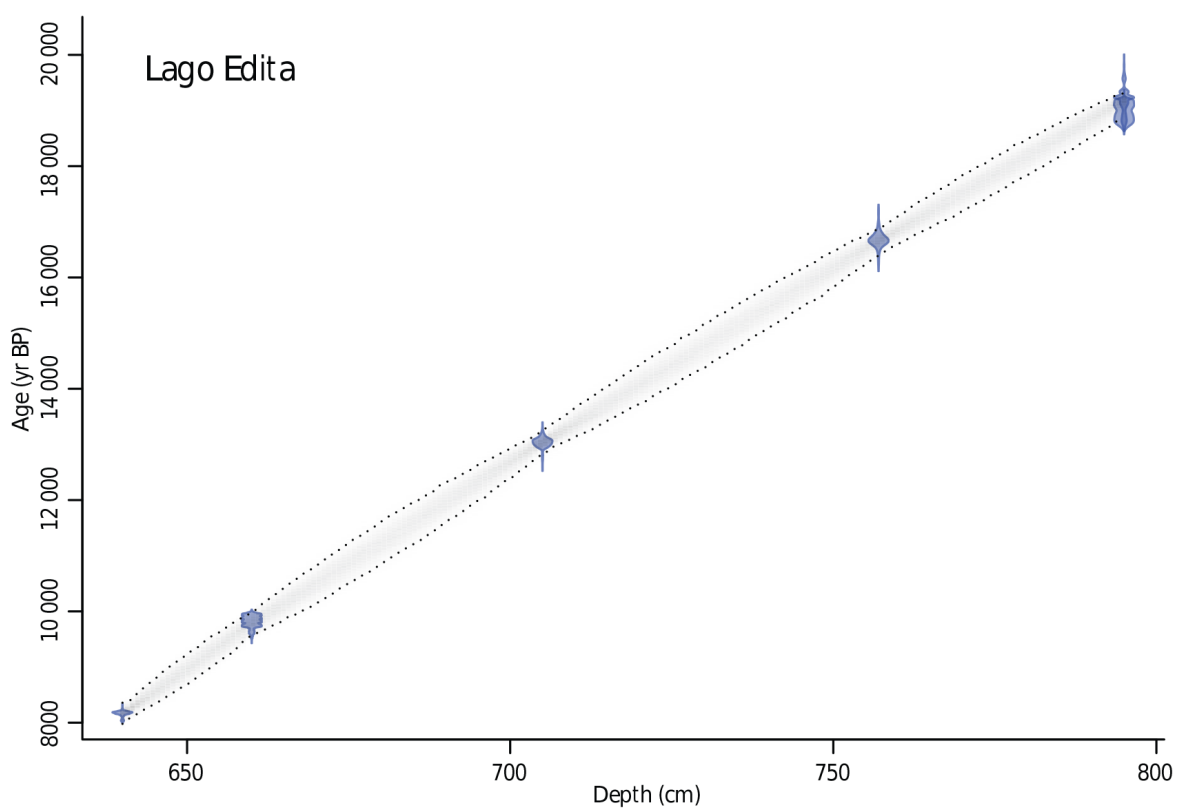

Figure 3. Age model of the Lago Edita record, with the blue zones representing the probability distribution of the calibrated radiocarbon dates and the grey zone representing the calculated confidence interval of the Bayesian age model.

Table 1. Radiocarbon dates from the Lago Edita core. The radiocarbon dates were calibrated to calendar years before present using the CALIB 7.0 program.

\begin{tabular}{lllrrrr}
\hline Laboratory code & Core & Material & $\begin{array}{r}\text { Length } \\
(\mathrm{cm})\end{array}$ & ${ }^{14}$ C yr BP $\pm 1 \sigma$ & $\begin{array}{r}\text { Median probability } \\
(\mathrm{yr} B P)\end{array}$ & $2 \sigma$ range (yr BP) \\
\hline UCIAMS-133501 & PC0902AT7 & Bulk & $660-661$ & $8935 \pm 25$ & 10029 & $9794-10177$ \\
UCIAMS-133416 & PC0902AT8 & Bulk & $705-706$ & $11350 \pm 60$ & 13229 & $13109-13350$ \\
UCIAMS-133417 & PC0902AT8 & Bulk & $757-758$ & $13740 \pm 70$ & 16863 & $16684-17055$ \\
UCIAMS-133418 & PC0902AT8 & Bulk & $795-796$ & $16250 \pm 90$ & 19414 & $18934-19779$ \\
CAMS-144454 & PC0902BT8 & Bulk & $795-796$ & $16020 \pm 50$ & 19164 & $18922-19408$ \\
\hline
\end{tabular}

crease, while Poaceae shows fluctuations in its abundance between 2 and $16 \%$ over the entire interval. Other herbs and shrubs such as Ericaceae $(3 \%)$, Phacelia $(\sim 2 \%)$, Valeriana $(1 \%)$, Gunnera magellanica $(\sim 2 \%)$, Apiaceae $(<1 \%)$, and Asteraceae subfamily Cichorioideae $(<1 \%)$ remain relatively steady. The arboreal taxa $N$. dombeyi type (10\%), Fitzroya/Pilgerodendron (2\%), P. nubigena $(<1 \%)$ and $D$. winteri $(<1 \%)$ are present in low abundance, as well as the ferns L. magellanicum $(\sim 1 \%)$ and Blechnum type $(5 \%)$ and the green microalgae Pediastrum (2\%).

Zone Edita-2 (780-758 cm; 18 100-16800 yr BP) begins with a decline in Empetrum (30\%) and an increase in Poaceae $(34 \%)$, followed by its decrease until the end of this zone. $N$. dombeyi type (15\%), Caryophyllaceae (5\%) and Asteraceae subfamily Asteroideae (5\%) show a rising trend in this zone, while other arboreal taxa (Fitzroya/Pilgerodendron (3\%), P. nubigena $(<1 \%)$ and D. winteri $(<1 \%)$ and most of the herbs maintain an abundance similar to that of the previous zone. L. magellanicum $(2 \%)$ and Pediastrum (4\%) rise slightly, and high variability in Cyperaceae $(7 \%)$ is shown.

Zone Edita-3 (758-701 cm; 16 800-13 $200 \mathrm{yr} \mathrm{BP)} \mathrm{is} \mathrm{char-}$ acterized by a sharp rise in Poaceae $(45 \%)$ and a declining trend in Empetrum (15\%). The conifer P. nubigena $(2 \%)$ starts a sustained increase, while $N$. dombeyi type (13\%) and Fitzroya/Pilgerodendron (3\%) remain relatively invariant. $D$. winteri $(<1 \%)$ and Misodendrum $(<1 \%)$, a mistletoe that grows on the Nothofagus species, appear in low abundance in an intermittent manner. Pediastrum (30\%) shows a rapid increase until $15600 \mathrm{yr} \mathrm{BP}$, followed by considerable variations in its abundance until the end of this zone (between 19 and $55 \%)$. L. magellanicum (3\%) shows a steady increase, while Blechnum type (6\%) remains invariant and Cyperaceae $(7 \%)$ exhibits large fluctuations superimposed upon a declining trend.

Zone Edita-4 (701-681 cm; 13 200-11 600 yr BP) starts with an increase in $N$. dombeyi type (29\%) and a minor rise in Misodendrum (1\%). P. nubigena (5\%) starts this zone 

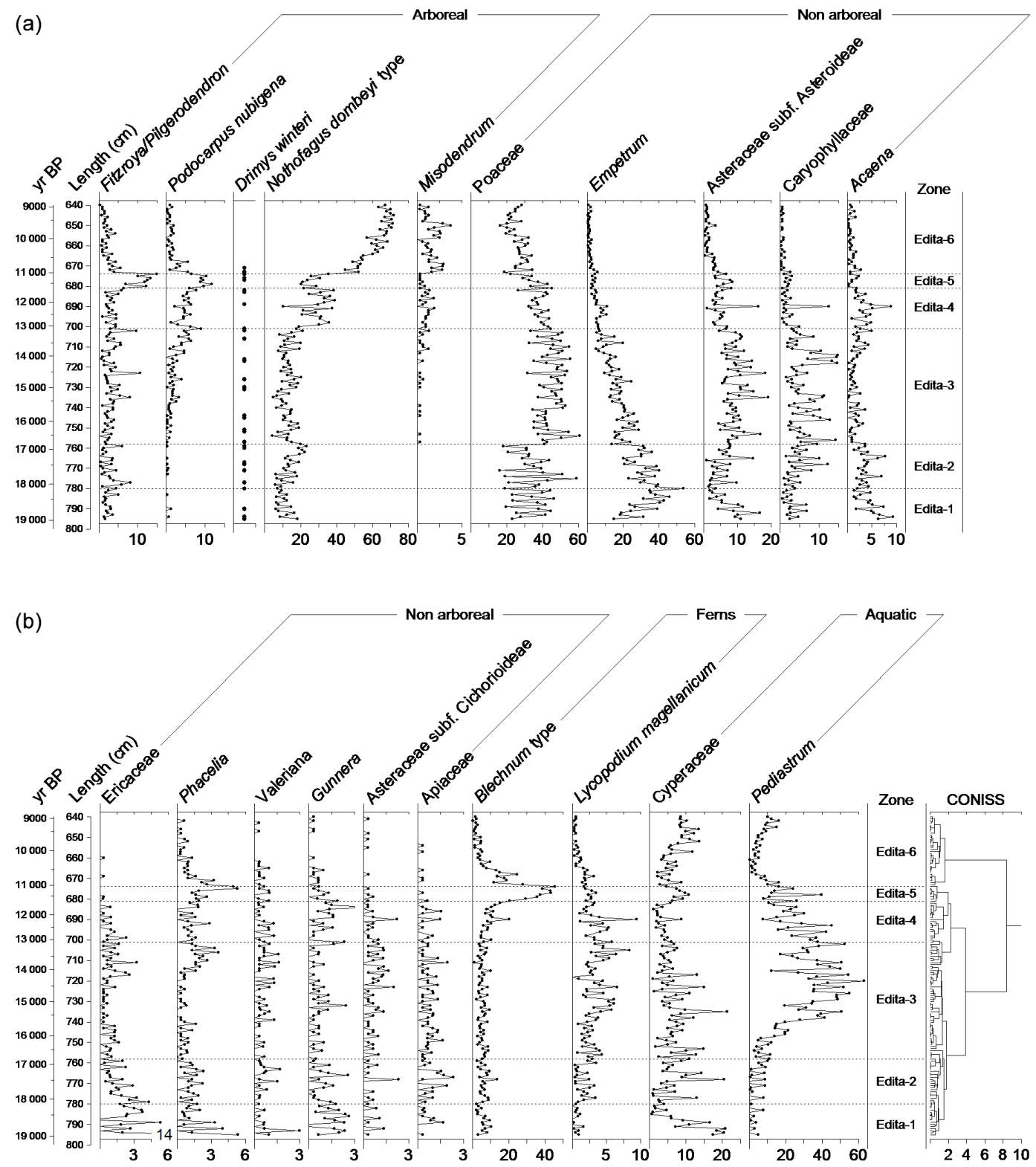

Figure 4. Percentage pollen diagrams from the Lago Edita core. The labels on the right indicate the identity and stratigraphic span (dashed horizontal lines) of each pollen assemblage zone. The black dots indicate the presence of Drimys winteri pollen grains, normally $<2 \%$.

with variability and stabilizes toward the end, concurrent with Fitzroya/Pilgerodendron (3\%) and traces of D. winteri $(<1 \%)$. Poaceae $(38 \%)$ shows a steady decrease, while $\mathrm{Em}$ petrum $(6 \%)$ continues with a declining trend that started during the previous zone. Asteraceae subfamily Asteroideae $(5 \%)$ and Caryophyllaceae (2\%) decrease, L. magellanicum (3\%), Cyperaceae (4\%) and Pediastrum (24\%) decline gradually with considerable fluctuations, while Blechnumtype $(11 \%)$ shows modest increases.

Zone Edita-5 (681-674 cm; 11 600-11 $100 \mathrm{yr}$ BP) shows marked declines in $N$. dombeyi type (27\%) and Poaceae $(33 \%)$ in concert with a noticeable increase in the conifers
Fitzroya/Pilgerodendron (12\%) and P. nubigena (9\%), which reach their peak abundance in the record. The abundance of herbs and shrubs decreases or remains steady, with the exception of an ephemeral increase in Phacelia (3\%). Blechnum type (39\%) shows a remarkable increase to its peak abundance in the entire record, while L. magellanicum (3\%), Cyperaceae (8\%) and Pediastrum (17\%) rise slightly.

Zone Edita-6 $(674-640 \mathrm{~cm} ; 11100-8940 \mathrm{yr} \mathrm{BP})$ is characterized by an abrupt increase in $N$. dombeyi type (62\%) and Misodendrum (2\%), along with a noticeable decline in Fitzroya/Pilgerodendron (2\%) and P. nubigena (2\%) at the beginning of this zone. Poaceae (26\%) shows a downward 
trend over this period, while other herbs and shrubs (Empetrum, Ericaceae, Caryophyllaceae, Asteraceae subfamily Asteroideae, Acaena, Phacelia, Valeriana, Gunnera magellanica, Apiaceae and Asteraceae subf. Cichorioideae) show their lowest abundance in the record. Blechnum type (7\%) drops sharply, followed by a gradual decline in concert with L. magellanicum (1\%). Cyperaceae (7\%) and Pediastrum $(6 \%)$ show initial declines followed by increases toward the end of this zone.

\subsection{Charcoal stratigraphy}

The record from Lago Edita shows absence of macroscopic charcoal particles between 19000 and $14300 \mathrm{yr}$ BP followed by an increase in charcoal accumulation rate (CHAR) that led to a variable plateau between 13200 and $12000 \mathrm{yr}$ BP, a 1000-year-long decline, and a sustained increase led to peak abundance at $9700 \mathrm{yr}$ BP. Charcoal values then declined rapidly to intermediate levels by $9000 \mathrm{yr} \mathrm{BP}$. We note a close correspondence between the arboreal pollen abundance (as a percentage) and the CHAR, suggesting that charcoal production was highly dependent upon quantity and spatial continuity of coarse woody fuels in the landscape (Fig. 5).

Time series analysis of the macroscopic charcoal record revealed 11 statistically significant peaks we interpret as local fire events within the Lago Edita watershed (Fig. 5). The temporal structure of these events indicates a sequence of millennial-scale peaks in fire frequency, with maxima at 14 100, 13 100, 12 000, 10900 and 9600 yr BP. We observe a steady increase in the fire frequency maxima from 14100 to 10900 yr BP (Fig. 5).

\section{Discussion}

\subsection{Paleovegetation and paleoclimate}

Given the size of Lago Edita (radius $\sim 250 \mathrm{~m}$ ) its pollen record is adequate to reflect local vegetation within 600$800 \mathrm{~m}$ from the lake's edge. An extra-local component is also present considering that species of the genus Nothofagus also produce large quantities of pollen grains susceptible to long-distance transport (Heusser, 1989). These attributes suggest that the Lago Edita fossil pollen record might be a good sensor of the vegetation located on the western end of Valle Chacabuco and the Lago Cochrane basin. The record (Figs. 4, 6) documents dominance of herbs and shrubs (chiefly Poaceae, Empetrum and Asteraceae, accompanied by Caryophyllaceae, Acaena, Ericaceae, Phacelia, Valeriana, and Apiaceae in lower abundance) found above the modern tree line and the Patagonian steppe between 19000 and $11000 \mathrm{yr} \mathrm{BP}$, followed by increasing Nothofagus. We interpret this as the establishment of scrubland $(\sim 13000$ $11000 \mathrm{yr} \mathrm{BP})$, woodland $(\sim 11000-10500 \mathrm{yr} \mathrm{BP})$ and forest ( $\sim 10500-9000 \mathrm{yr}$ BP). Within the interval dominated by non-arboreal taxa, we distinguish an initial phase with abun-
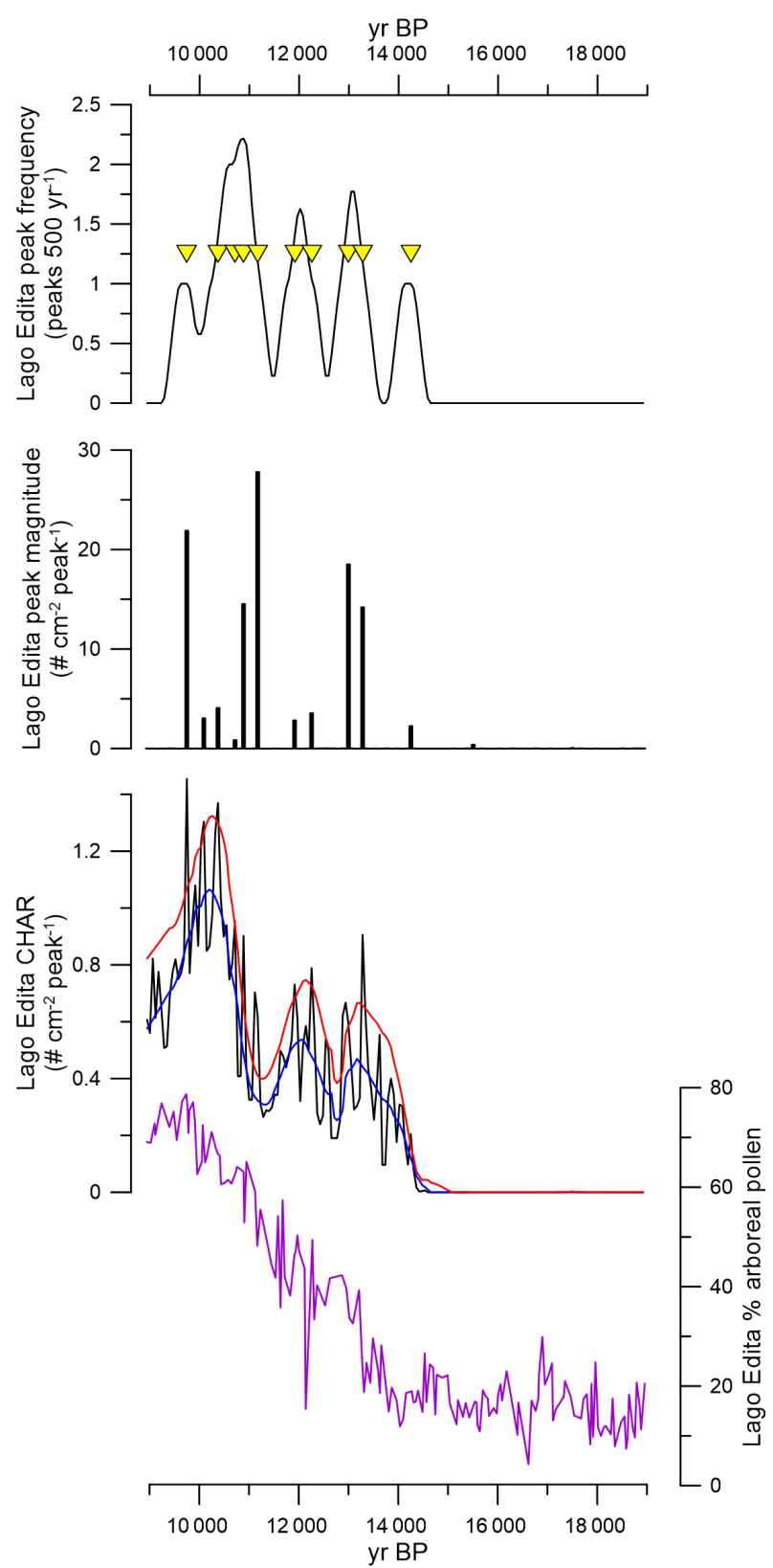

Figure 5. Macroscopic charcoal record from the Lago Edita core and results of CharAnalysis: the blue line is the background component, the red line is the locally defined threshold, triangles are statistically significant charcoal peaks and magnitude is the residual abundance that supersedes the threshold. CHAR is the charcoal accumulation rate.

dant Empetrum between 19000 and 16800 yr BP, followed by diversification of the herbaceous assemblage and predominance of Poaceae during the interval $\sim 16800-11000 \mathrm{yr}$ BP (Figs. 4, 6). This change is contemporaneous with a sustained rise in P. nubigena and the mistletoe Misodendrum coeval with conspicuous increases in Lycopodium magellanicum and the green microalgae Pediastrum. We em- 

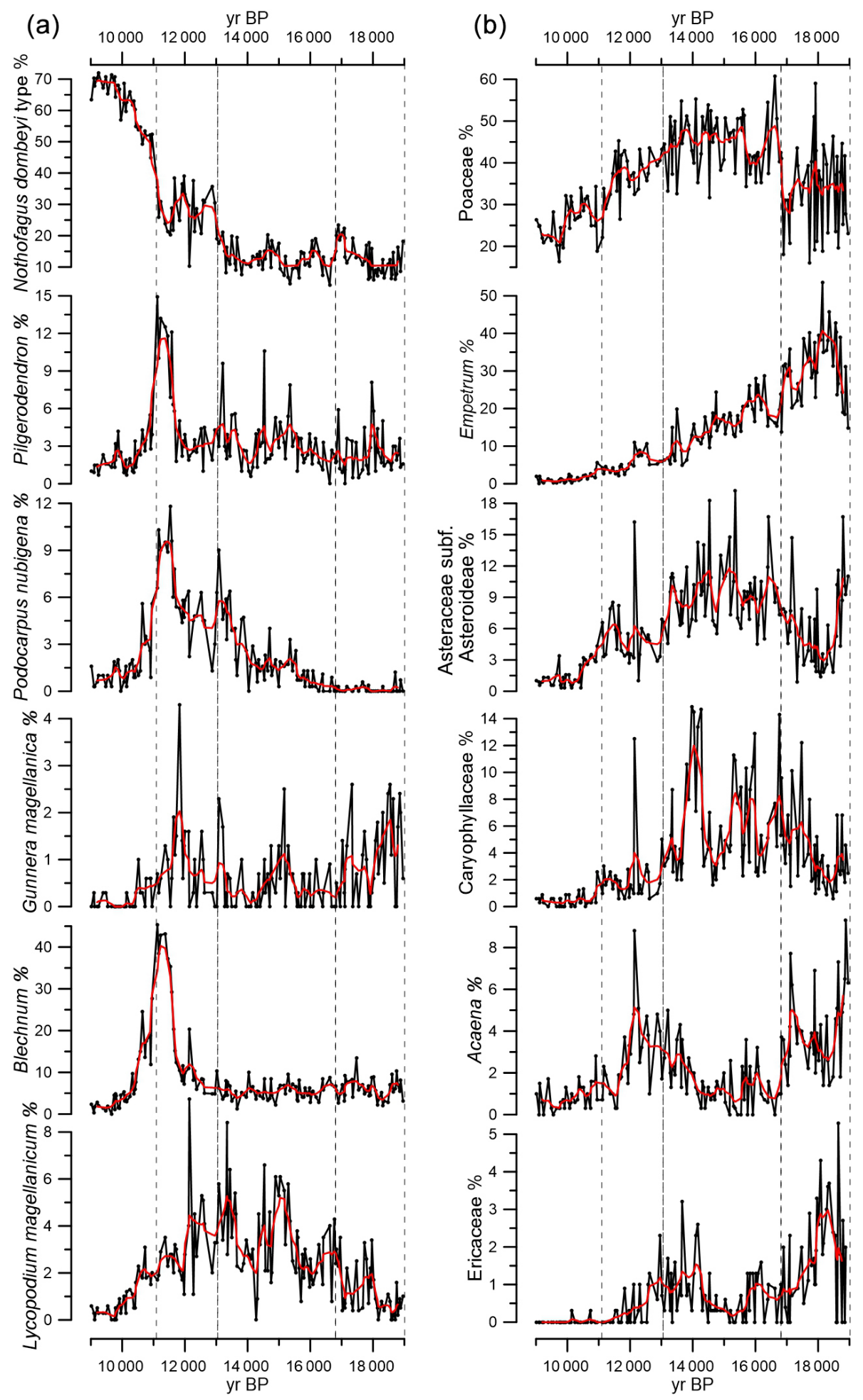

Figure 6. Selected palynomorph abundance of the Lago Edita record shown in the timescale domain. The red lines correspond to weighted running means of seven adjacent samples with a triangular filter. The taxa shown in the left panel are characteristic of humid environments currently found in sectors adjacent to the Pacific coast and/or the Andean tree line in the study area. The taxon Nothofagus dombeyi type, which includes multiple species with contrasting climatic tolerances, is also found in (relatively) humid sectors east of the Andes. The herbs and shrubs shown in the right panel are either cosmopolitan or present in the Patagonian steppe and sectors located at or above the Andean tree line in central-western Patagonia. 
phasize the continuous presence of the arboreal Nothofagus and Fitzroya/Pilgerodendron in low but constant abundance $(\sim 15$ and $\sim 3 \%$, respectively) between 19000 and $13000 \mathrm{yr}$ BP, along with traces $(<2 \%)$ of hygrophilous trees (Podocarpus nubigena, Drimys winteri) and herbs (Gunnera magellanica, Lycopodium magellanicum) accounting, in sum, for a persistent $\sim 25 \%$ of the pre-13 $200 \mathrm{yr}$ BP pollen record (Figs. 4, 6). We note that the Nothofagus parkland on the western end of Valle Chacabuco and the Lago Cochrane basin must have approached the vicinity of Lago Edita at $16800 \mathrm{yr}$ BP, judging from the appearance of Misodendrum during that time (Figs. 4, 6) under relatively constant mean Nothofagus abundances.

The conifer Podocarpus nubigena remained in low abundance $(<2 \%)$ prior to $\sim 14500 \mathrm{yr} \mathrm{BP}$ in the Lago Edita record, increased between 14500 and $13000 \mathrm{yr}$ BP, experienced a variable decline between 13000 and $11800 \mathrm{yr} \mathrm{BP}$, reached a maximum between 11800 and $11200 \mathrm{yrBP}$, and declined between 11200 and $10200 \mathrm{yr} \mathrm{BP}$ (Figs. 4, 6). This cold-resistant hygrophilous tree is commonly found in temperate evergreen rainforests along the Pacific coast of central Patagonia and is currently absent from the eastern Andean foothills at the same latitude. Its presence and variations in the Lago Edita record suggest an increase in precipitation relative to the pre-14500 yr BP conditions, with millennialscale variations starting at $\sim 13000 \mathrm{yr} \mathrm{BP}$. The variable decline in $P$. nubigena at $13000 \mathrm{yr}$ BP coincided with an increase in Nothofagus that led to a variable plateau of $\sim 30 \%$ between 13000 and $11200 \mathrm{yr} \mathrm{BP}$, which we will discuss in the following paragraphs.

The mixed palynological assemblage between $\sim 19400$ and $11000 \mathrm{yr}$ BP has no modern analogues in the regional vegetation (Luebert and Pliscoff, 2006; Mancini, 2002). Possible explanations for its development involve (a) downslope migration of high-Andean vegetation driven by snow line and tree line lowering associated with intense glaciation in the region, coupled with (b) the occurrence of scattered, lowdensity populations of hygrophilous trees and herbs along the eastern margin of the PIS during the LGM and T1. We rule out the alternative explanation that pollen grains and spores of hygrophilous trees and herbs in Lago Edita represent an advected signal through the Andes from ice-free humid Pacific sectors harboring these species because (i) no empirical basis is currently available for ice-free conditions and the occurrence of cold-resistant hygrophilous taxa along the western Andean slopes or the Pacific coast of central Patagonia during the LGM. In fact, the oldest minimum limiting dates for ice-free conditions in records from the Taitao Peninsula and the Chonos Archipelago yielded ages of $14335 \pm 140$ and $13560 \pm 125{ }^{14} \mathrm{C}$ yr BP (median age probability, MAP: 17458 and $16345 \mathrm{yr} \mathrm{BP}$ ), respectively (Haberle and Bennett, 2004; Lumley and Switsur, 1993). (ii) The appearance of Fitzroya/Pilgerodendron and Podocarpus nubigena at $\sim 15000$ and $\sim 14000 \mathrm{yr}$ BP, respectively, occurred 4000 5000 years later in coastal Pacific sites relative to the Lago
Edita record (Fig. 7), and (iii) background levels of Nothofagus between 15 and $20 \%$ in Lago Edita predate the appearance and expansion of this taxon in coastal Pacific sites and, once realized, its abundance in Lago Edita cannot be attributed to long-distance transport from the western Pacific coast (Fig. 7).

Previous palynological studies from bogs located east of the central Patagonian Andes (de Porras et al., 2012; Markgraf et al., 2007) (Mallín Lago Shaman and Mallín Pollux, Fig. 1) interpreted dry conditions prior to $\sim 12000 \mathrm{yr} \mathrm{BP}$, based on the premise that low abundance of arboreal taxa and predominance of herbs and shrubs were indicative of Patagonian Steppe communities. The glacial-to-interglacial vegetation change in those studies was interpreted as a westward shift of the forest-steppe boundary brought by lowerthan-present SWW influence at $44-46^{\circ} \mathrm{S}$, followed by a rise in temperature and precipitation at the end of the last glaciation. In contrast, the Lago Augusta site (located in Valle Chacabuco $\sim 7 \mathrm{~km}$ northeast of Lago Edita) (Fig. 1) shows a pollen assemblage prior to $15600 \mathrm{yr}$ BP dominated by high-Andean herbs and shrubs, along with taxa characteristic of hyper-humid environments along the Pacific coasts of central Patagonia (Nothofagus, Fitzroya/Pilgerodendron, Podocarpus nubigena, Saxegothaea conspicua, Drimys winteri, Dysopsis glechomoides and the ferns Blechnum, Hymenophyllaceae and Cystopteris) (Villa-Martinez et al., 2012). It appears then that floristic elements of modern Patagonian forests were present in low abundance and in a discontinuous manner along the eastern flank of the PIS between 44 and $47^{\circ} \mathrm{S}$. The data from Lago Edita shown in this paper, along with the results from Lago Augusta, suggest that Valle Chacabuco harbored cryptic refugia (Bennett and Provan, 2008) of rainforest trees and herbs during the interval 19000-11 $000 \mathrm{yr}$ BP. Therefore, the interpretation of lower-than-present precipitation of SWW origin in previous studies (de Porras et al., 2012; Markgraf et al., 2007) is not applicable to the Valle Chacabuco area over this time interval. Plant colonization of Valle Chacabuco must have started from the LGM limits located east of Lago Cochrane and followed the shrinking ice masses to the west once the newly deglaciated sectors were devoid of glaciolacustrine influence through $\mathrm{T} 1$.

Declines in and the virtual disappearance of the coldresistant hygrophilous trees Fitzroya/Pilgerodendron and Podocarpus nubigena along with the herbs Gunnera magellanica and Lycopodium magellanicum took place at $\sim 11000 \mathrm{yr} \mathrm{BP}$ in the Lago Edita record (Figs. 4, 6) in response to a sudden decline in precipitation relative to the $\sim 14500-11000 \mathrm{yr}$ BP interval. These changes were contemporaneous with a sustained rise in Nothofagus, decreases in all other shrubs and herbs and a major increase in macroscopic charcoal (Fig. 5), signaling an increment in arboreal cover, higher spatial continuity of coarse fuels and forest fires. We interpret this arboreal increase and fire-regime shift as driven by warming, which might have triggered a tree line 
Nothofagus dombeyi type \%
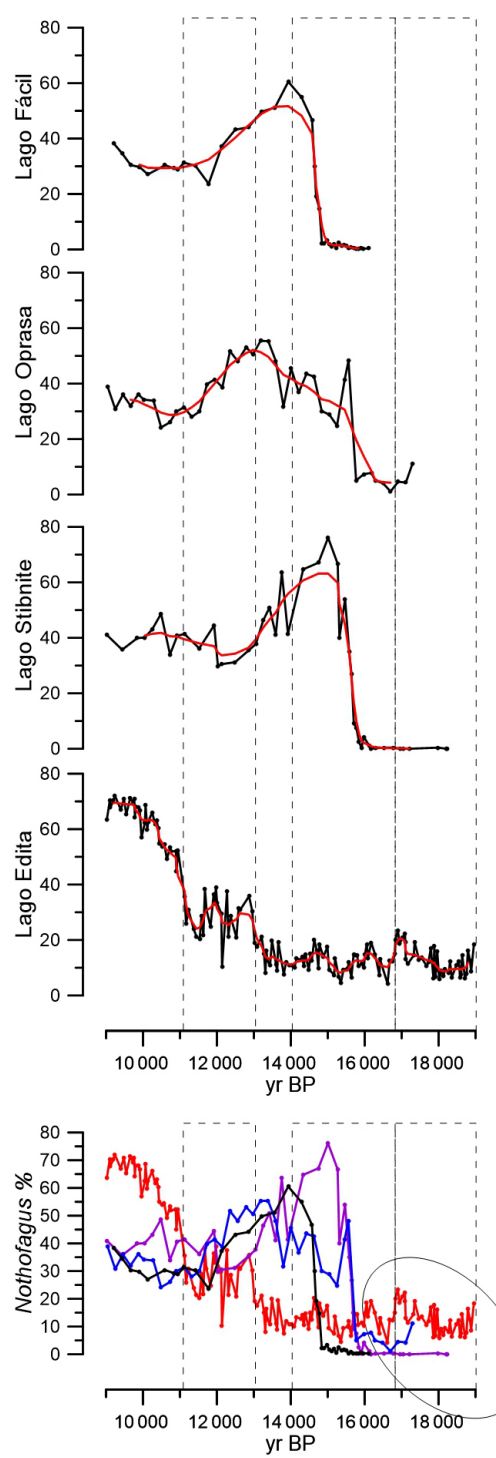

Pilgerodendron type \%
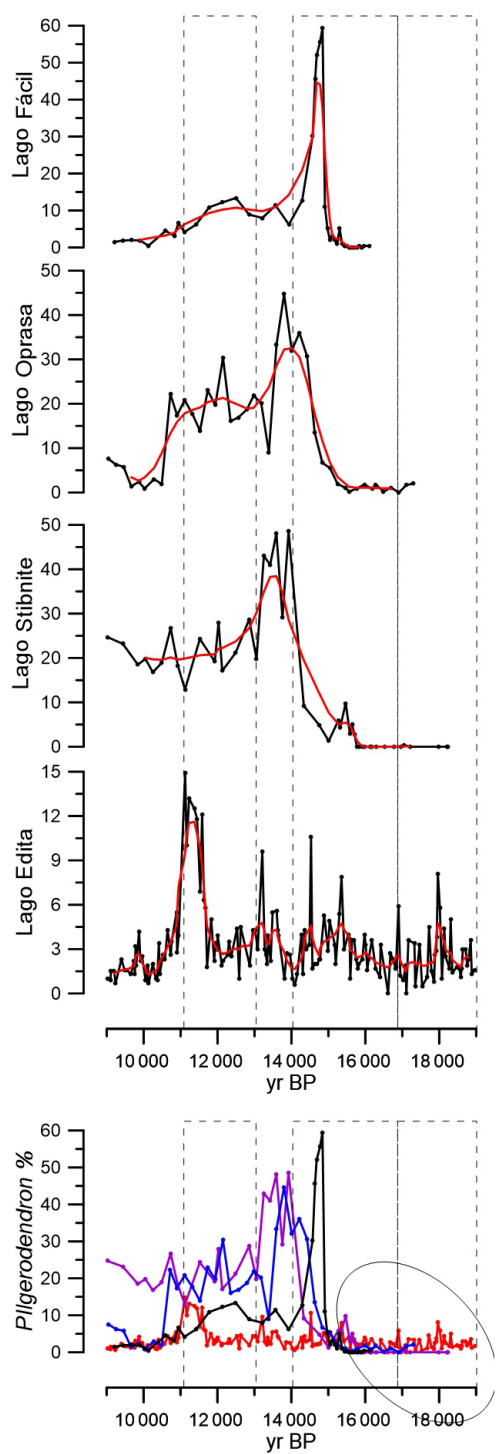

Podocarpus nubigena \%
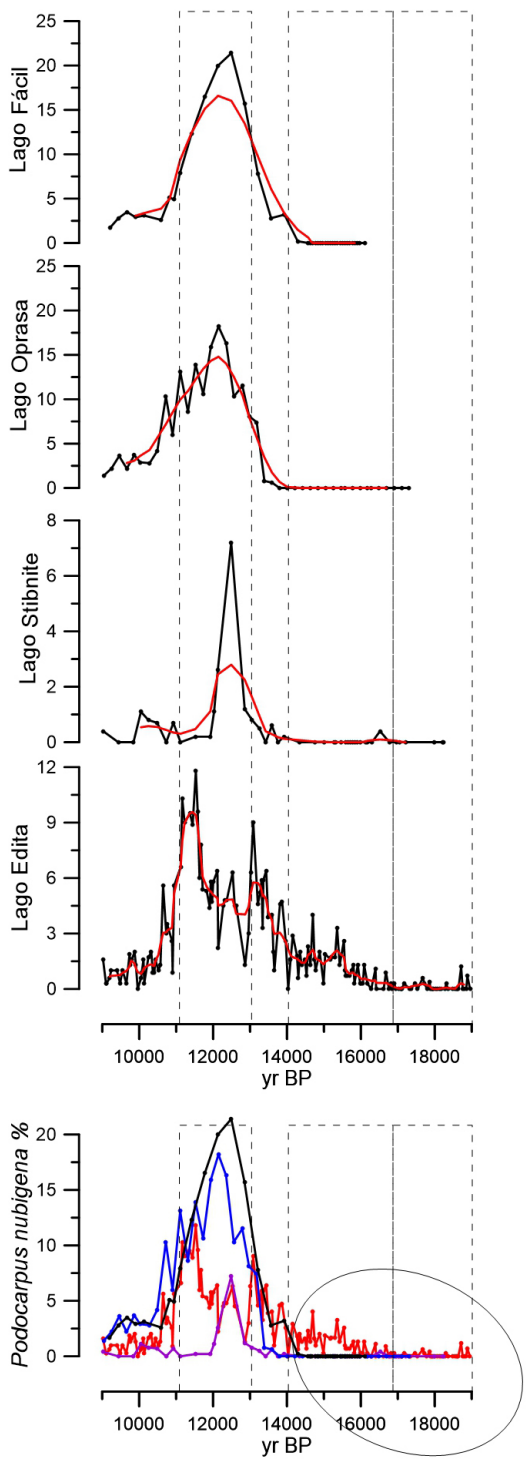

Figure 7. Comparison of selected tree pollen recorded in Lago Fácil, Lago Oprasa, Lago Stibnite (Lumley and Switsur, 1993) and Lago Edita. The red line corresponds to a weighted running mean in each record of seven adjacent samples with a triangular filter. The lower panels show the curves from all sites expressed in a common percent scale (Lago Fácil is the purple line, Lago Oprasa is the blue line, Lago Stibnite is the black line and Lago Edita is the red line).

rise and favored the spread and/or densification of woody species and coarse fuels (Figs. 4, 5, 6). Possible ignition agents for the beginning of fire activity at $14300 \mathrm{yr}$ BP in the Lago Edita record include the incendiary effects of explosive volcanic activity, lightning strikes and human activity. We rule out volcanic disturbance as a driving factor, considering the lack of contemporary tephras in the stratigraphy of the Lago Edita sediment cores, and we cannot support nor reject other ignition agents considering the current lack of stratigraphic proxies to constrain their likely influence in the Valle Chacabuco area. Finally, Nothofagus forests ( $\sim 70 \%$ abun- dance) were established near Lago Edita between 10000 and 9000 yr BP.

\subsection{Glacial recession in Valle Chacabuco and the Lago Cochrane basin}

Stratigraphic and chronological results from Lago Edita are key for deciphering the evolution of Valle Chacabuco and for constraining the timing and rates of deglaciation in this core region of the PIS. Previous studies (Hein et al., 2010) indicate that Valle Chacabuco was overridden by the LCIL during the LGM and deposited the Río Blanco 
moraines $\sim 90 \mathrm{~km}$ downstream from Lago Edita, distal to the eastern end of Lago Cochrane in Argentina (Argentinian name: Pueyrredón). Cosmogenic radionuclide dating of three main moraine limits by Hein et al. (2010) yielded cosmogenic ${ }^{10} \mathrm{Be}$ exposure ages, recently recalculated by Kaplan et al. (2011) at $\sim 21100, \sim 25100$ and $\sim 28700 \mathrm{yr}$ BP. This was followed by glacial recession starting at $19600 \pm 800 \mathrm{yr}$ BP, formation of GLC and stabilization and deposition of the Lago Columna and Lago Posada moraines before $17600 \pm 900 \mathrm{yr}$ BP $\sim 55 \mathrm{~km}$ upstream from the Río Blanco moraines (Hein et al., 2010; Kaplan et al., 2011) (Fig. 1). Further glacial recession led to the westward expansion and lowering of GLC until the LCIL stabilized and deposited moraines in Lago Esmeralda between 13600 and $12800 \mathrm{yr} \mathrm{BP} \sim 60 \mathrm{~km}$ upstream from the Lago Columna and Lago Posada moraines (Turner et al., 2005). Recession from this position led to sudden drainage of GLC toward the Pacific Ocean via Río Baker, once the continuity between the northern and southern Patagonian ice fields was breached by glacial recession and thinning. These data suggest that Valle Chacabuco may have been ice-free and devoid of glaciolacustrine influence after $\sim 17600 \mathrm{yr}$ BP. More recently, Boex et al. (2013) reported a cosmogenic radionuclide-based reconstruction of vertical profile changes of the LCIL through the LGM and T1 that reveals deposition of (i) the Sierra Colorado lower limit by $28980 \pm 1206 \mathrm{yr}$ BP, which can be traced to the Río Blanco moraines; (ii) the highest summits of the Cerro Oportus and Lago Columna moraines by $18966 \pm 1917 \mathrm{yr}$ BP; and (iii) the María Elena moraine by $17088 \pm 1542$ yr BP. According to these data, Valle Chacabuco may have been ice-free after $\sim 17000 \mathrm{yr}$ BP.

Lago Edita is a closed-basin lake located $\sim 11 \mathrm{~km}$ east of the Cerro Tamango summit along the ridge that defines the southern edge of the Valle Chacabuco watershed (Fig. 1). Lacustrine sedimentation in Lago Edita started when ice-free conditions developed in Valle Chacabuco, as the LCIL snout retreated eastward to a yet unknown position. The Lago Edita cores show $9 \mathrm{~m}$ of blue-gray clays with millimeter-scale laminations, interrupted by sporadic intervals of massive pebbly mud appreciable in $\mathrm{X}$ radiographs and the $\mathrm{LOI}_{550}$ record as increases in the inorganic density data (Fig. 2). We also found exposed glaciolacustrine beds and discontinuous fragments of lake terraces in the vicinity of Lago Edita, attesting for a large lake that flooded Valle Chacabuco in its entirety. Differential GPS measurements of $570 \mathrm{~m}$ a.s.l. for the Lago Edita surface and $591 \mathrm{~m}$ a.s.l. for a well-preserved terrace fragment located $\sim 150 \mathrm{~m}$ directly south of Lago Edita provide minimum-elevation constraints for GLC during this stage. The Lago Augusta site (Villa-Martinez et al., 2012), located $\sim 7 \mathrm{~km}$ northeast of Lago Edita on the Valle Chacabuco floor at $444 \mathrm{~m}$ a.s.l. (Fig. 1), shows $8 \mathrm{~m}$ of basal glaciolacustrine mud (Fig. 2), lending support to our interpretation.

Glaciolacustrine sedimentation persisted in Lago Edita and Lago Augusta until the surface elevation of GLC dropped below 570 and 444 ma.s.l., respectively, and the closed-basin lakes developed. The chronology for this event is constrained by statistically identical AMS dates of $16250 \pm 90$ and $16020 \pm 50{ }^{14} \mathrm{C}$ yr BP (UCIAMS-133418 and CAMS-144454, respectively) (Table 1) from the same level in the basal portion of the organic sediments in the Lago Edita record; this estimate approaches the timing for the cessation of glaciolacustrine influence in Lago Augusta, radiocarbon-dated at $16445 \pm 45{ }^{14} \mathrm{C}$ yr BP (CAMS-144600) (Table 1). Because we observe approximately the same age for the transition from glaciolacustrine to organic-rich mud in both stratigraphic layers, we interpret the weighted mean age of those three dates $\left(16254 \pm 63{ }^{14} \mathrm{C}\right.$ yr BP, MAP: $19426 \mathrm{yr}$ BP, two different laboratories) as a minimum-limiting age for ice-free conditions and nearly synchronous glaciolacustrine regression from elevations 591 and $444 \mathrm{~m}$ a.s.l. in Valle Chacabuco. We acknowledge that Villa-Martínez et al. (2012) excluded the age of date CAMS-144600 from the age model of the Lago Augusta palynological record because it was anomalously old in the context of other radiocarbon dates higher up in the core.

Comparison of the radiocarbon-dated stratigraphy from the Lago Edita record with the exposure-age-dated glacial geomorphology from Lago Cochrane (Pueyrredón), Valle Chacabuco and the surrounding mountains reveals the following:

- The geochronology for the innermost (third) belt of Río Blanco moraines ( $21100 \mathrm{yr}$ BP) (Hein et al., 2010; Kaplan et al., 2011), glacial deposits on the highest summits of Cerro Oportus and the Lago Columna moraines (18 966 \pm 1917 yr BP) (Boex et al., 2013) is compatible (within error) with the onset of organic sedimentation in Lago Edita and Lago Augusta at $19426 \mathrm{yr} \mathrm{BP}$ in Valle Chacabuco. If correct, this indicates a $\sim 90 \mathrm{~km}$ recession of the LCIL from its LGM limit within $\sim 1500$ years.

- The dates of Hein et al. (2010) for the final LGM limit and Lago Columna and Lago Posada moraines, as well as the chronology of Boex et al. (2013) for the María Elena moraine, should be considered as minimumlimiting ages. This is because cosmogenic radio nuclide ages for these landforms postdate the onset of organic sedimentation in Lago Edita and Lago Augusta, despite being morphostratigraphically distal (older) than Valle Chacabuco.

- As shown in Fig. 1, Lago Edita is located along a saddle that establishes the southern limit of the Río Chacabuco catchment and the northern limit of the Lago Cochrane basin. According to Hein et al. (2010) the drainage divide on the eastern end of the Lago Cochrane (Pueyrredón) basin is located at $475 \mathrm{~m}$ a.s.l.; therefore, the presence of this perched glacial lake with a surface elevation of $591 \mathrm{~m}$ a.s.l. requires the presence of 
ice dams located in the Valle Chacabuco and the Lago Cochrane basin. This suggests that both valleys remained partially ice covered and that enough glacier thinning and recession early during $\mathrm{T} 1$ enabled the development of a topographically constrained glacial lake that covered Valle Chacabuco up to the aforementioned saddle.

- The high stand of GLC at $591 \mathrm{ma.s.1}$. lasted for less than 1500 years during the LGM and was followed by a nearly instantaneous lake-level lowering of at least $\sim 150 \mathrm{~m}$ at $\sim 19400 \mathrm{yr}$ BP in Valle Chacabuco. The abrupt large-magnitude drainage event of this predecessor lake was recently recognized by Bourgois et al. (2016), but its chronology and hydrographic and climatic implications have not been addressed in the Quaternary literature.

\subsection{Biogeographic and paleoclimatic implications}

The persistence of scattered, low-density populations of rainforest trees and herbs east of the Andes during the LGM and T1 (Figs. 4, 6) implies that precipitation delivered by the SWW must have been substantially higher than at present (680 mm year $^{-1}$ measured at the Cochrane meteorological station). Because local precipitation in western Patagonia is positively and significantly correlated with low-level zonal winds (Garreaud et al., 2013; Moreno et al., 2010, 2014), we propose that the SWW influence at $47^{\circ} \mathrm{S}$ was stronger than present between 19000 and $11000 \mathrm{yr} \mathrm{BP}$, in particular between 16800 and 11000 yr BP. Subsequent increases in arboreal vegetation, chiefly Nothofagus, at $\sim 13000$ and $\sim 11000 \mathrm{yr}$ BP led to the establishment of forests near Lago Edita between 10000 and 9000 yr BP (Figs. 4, 6). We interpret these increases as episodes of tree line rise driven by warming pulses coupled with a decline in SWW strength at $47^{\circ} \mathrm{S}$ (relative to the $\sim 14500-11000 \mathrm{yr}$ BP interval), as suggested by the disappearance of cold-resistant hygrophilous trees and herbs at $\sim 11000 \mathrm{yr} \mathrm{BP}$. We speculate that the warm pulse and decline in SWW influence at $\sim 11000 \mathrm{yr}$ BP might account for the abandonment of early Holocene glacier margins in multiple valleys in central Patagonia (Glasser et al., 2012).

Five salient aspects of the Lago Edita record are relevant for deciphering the pattern and rates of climate change and dispersal routes of the vegetation in Central Patagonia $\left(47^{\circ} \mathrm{S}\right)$ during T1:

1. There is an absence of stratigraphically discernable indications of deglacial warming between 19400 and $13000 \mathrm{yr} \mathrm{BP}$, in contrast to northwestern Patagonian records (the Canal de la Puntilla-Huelmo record, Fig. 1) (Moreno et al., 2015), which show that 75-80\% of the glacial-interglacial temperature recovery was accomplished between 17800 and $16800 \mathrm{yr}$ BP (Fig. 8). The record from Lago Stibnite $\left(46^{\circ} 26^{\prime} \mathrm{S}, 74^{\circ} 25^{\prime} \mathrm{W}\right)$, located in central-western Patagonia upwind from the PIS and Lago Edita (Fig. 1), shows a rapid increase in arboreal pollen from $\sim 2 \%$ to $>80 \%$ in less than 1000 years starting at $16200 \mathrm{yr} \mathrm{BP}$ (Fig. 8). We posit that cold glacial conditions lingered along the periphery of the shrinking PIS during T1, affecting adjacent downwind sectors such as Valle Chacabuco. According to Turner et al. (2005) the LCIL stabilized and deposited moraines in Lago Esmeralda, located $\sim 10 \mathrm{~km}$ upstream along the glacier flow line and $\sim 240 \mathrm{~m}$ lower in elevation than Lago Edita, between 13600 and $12800 \mathrm{yr}$ BP. We propose that the climatic barrier for arboreal expansion vanished in downwind sectors such as Valle Chacabuco once glacial recession from the Lago Esmeralda (Fig. 1) margin breached the continuity of the northern and southern Patagonian ice fields along the Andes. Thus, we propose that regional cooling induced by the PIS along its eastern margin through $\mathrm{T} 1$ accounts for the delayed warming in Valle Chacabuco relative to records located in the western and northwestern sectors (Fig. 8).

2. Cold and wet conditions prevailed between 19400 and $16800 \mathrm{yr}$ BP, followed by an increase in precipitation at $16800 \mathrm{yr}$ BP. The latter event is contemporaneous with the onset of a lake-level rise in Lago Lepué $\left(43^{\circ} \mathrm{S}\right.$, central-east Isla Grande de Chiloé) (Fig. 8), which Pesce and Moreno (2014) interpreted as a northward shift of the SWW as it recovered from a prominent southward shift from latitude $\sim 41$ to $43^{\circ} \mathrm{S}$ (Fig. 8) following the onset of T1 (Moreno et al., 2015).

3. Significant ice recession $(\sim 90 \mathrm{~km})$ from the eastern LGM margin of the LCIL was accomplished between $\sim 21000$ and $19400 \mathrm{yr}$ BP, at times when northwestern Patagonian piedmont glacier lobes experienced moderate recession during the Varas interstade (Denton et al., 1999; Moreno et al., 2015) (Fig. 8). In contrast to the LCIL, northwestern Patagonian piedmont glacier lobes re-advanced to their youngest glacial maximum position during a cold episode between 19300 and $17800 \mathrm{yr} \mathrm{BP}$ that featured stronger SWW influence at $41-43^{\circ} \mathrm{S}$ (Moreno et al., 2015) (Fig. 8). One explanation for this latitudinal difference might be that northward-shifted SWW between 19300 and $17800 \mathrm{yr}$ BP fueled glacier growth in northwestern Patagonia while reducing the delivery of moisture to central Patagonia, causing the LCIL to continue the recession it had started during the Varas interstade.

4. A mosaic of cold-resistant and hygrophilous trees and herbs currently found along the humid western slopes of the Andes of central Chilean Patagonia and coldresistant shrubs and herbs common to high-Andean and Patagonian steppe communities developed along the eastern margin of the PIS during the LGM and T1 (Figs. 4, 6). We posit that glacial withdrawal and 


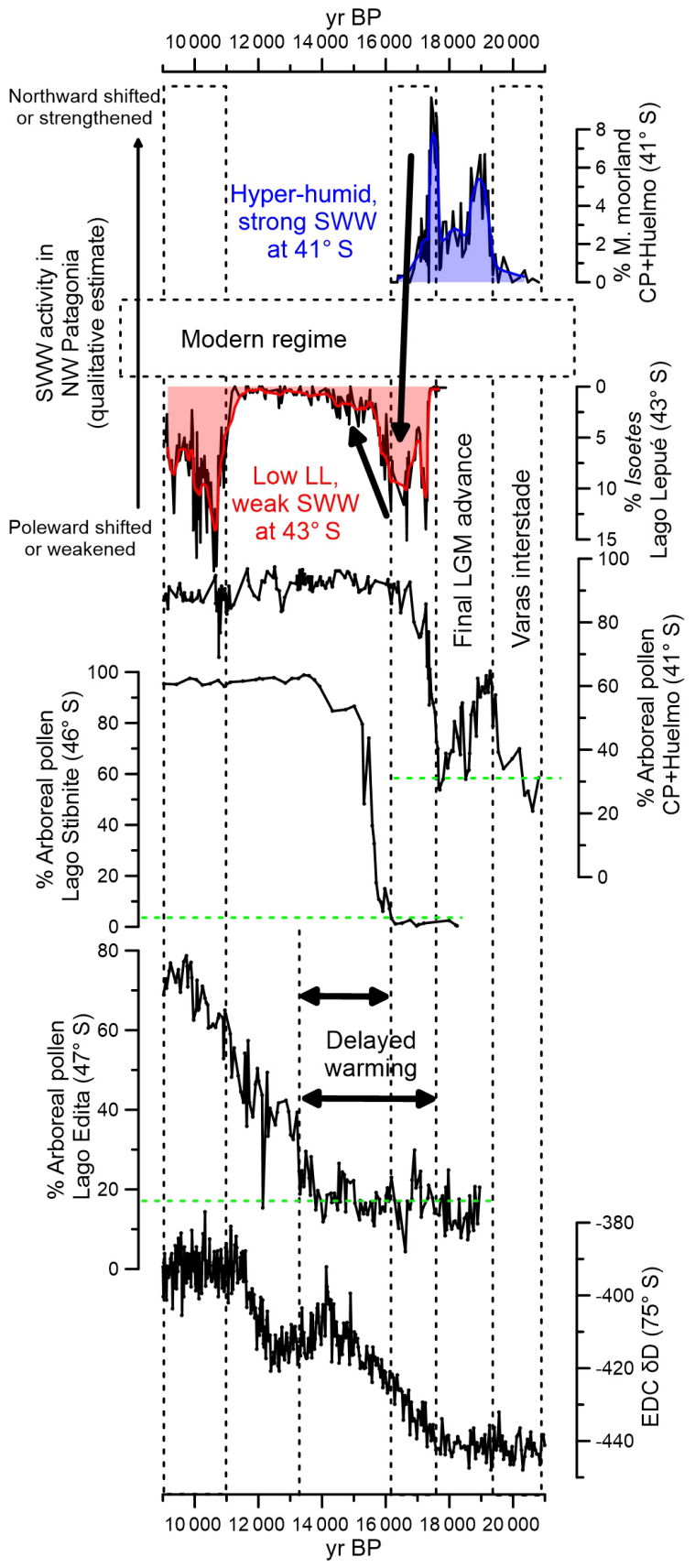

Figure 8. Comparison of the percent sum of arboreal pollen (AP) in records from Lago Edita, Lago Stibnite (Lumley and Switsur, 1993) and the spliced Canal de la Puntilla-Huelmo time series (Moreno et al., 2015), as proxies for local rise in tree line driven by deglacial warming. These data are compared to the delta Deuterium record from the EPICA Dome Concordia (EDC) ice core (Stenni et al., 2010), and hydrologic estimates from northwestern Patagonia. The latter consist of the percent abundance of Magellanic moorland species found in the spliced Canal de la Puntilla-Huelmo record (Moreno et al., 2015), indicative of a hyper-humid regime, and the percent abundance of the littoral macrophyte Isoetes savatieri from Lago Lepué (Pesce and Moreno, 2014), indicative of low lake level (LL) during the earliest stages of T1 and the early Holocene (9000-11 $000 \mathrm{yr}$ BP). The vertical dashed lines constrain the timing of the early Holocene SWW minimum at $41-43^{\circ} \mathrm{S}(9000-11000 \mathrm{yr} \mathrm{BP})$ (Fletcher and Moreno, 2011), a low-precipitation phase during the early termination at $41-43^{\circ} \mathrm{S}(16800$ $17800 \mathrm{yr}$ BP) associated with a southward shift of the SWW (Pesce and Moreno, 2014), the final LGM advance of piedmont glacier lobes (17 800-19300 yr BP) and the final portion of the Varas interestade (19300-21 000 yr BP) in the Chilean Lake District (Denton et al., 1999; Moreno et al., 2015). The dashed green horizontal lines indicate the mean AP of each pollen record prior to their increases during T1 (Lago Edita: $17 \%$, Lago Stibnite: $2 \%$, spliced Canal de la Puntilla-Huelmo: $31 \%$ ). The ascending oblique arrow represents a northward shift of the SWW the descending arrow represents a southward shift of the SWW at the beginning of T1. 
drainage of GLC through T1 provided a route for the westward dispersal of hygrophilous trees and herbs, contributing to the forestation of the newly deglaciated sectors of central-western Patagonia.

5. The cold-resistant hygrophilous conifer Podocarpus nubigena increased between 14500 and $13000 \mathrm{yr}$ BP, suggesting an increase in precipitation brought by the SWW to the eastern Andean slopes of central Patagonia. This was followed by a decline, which was contemporaneous with a rise in the regional Nothofagus-dominated tree line between 13000 and $11200 \mathrm{yr}$ BP. These interpretations imply stronger SWW influence of the SWW at $47^{\circ} \mathrm{S}$ during the Antarctic Cold Reversal and warming during Younger Dryas time.

We conclude that warm pulses at $\sim 13000$ and $\sim 11000 \mathrm{yrBP}$ and a decline in SWW influence at $47^{\circ} \mathrm{S}$ starting at $\sim 11000 \mathrm{yr} \mathrm{BP}$ brought $\mathrm{T} 1$ to an end in centralwestern Patagonia. The earliest of these events overlaps in timing with the culmination of Patagonian (Garcia et al., 2012; Moreno et al., 2009; Strelin et al., 2011; Strelin and Malagnino, 2000) and New Zealand glacier advances (Kaplan et al., 2010; Putnam et al., 2010) during the Antarctic Cold Reversal. Our data suggest that the subsequent warm pulse, which was accompanied by a decline in SWW strength at $11000 \mathrm{yr}$ BP (Moreno et al., 2010, 2012), was the decisive event that led to the end of T1 in the study area.

Data availability. Aspects of the record are available upon request to the corresponding author.

Competing interests. The authors declare that they have no conflict of interest.

Special issue statement. This article is part of the special issue "Southern perspectives on climate and the environment from the Last Glacial Maximum through the Holocene: the Southern Hemisphere Assessment of PalaeoEnvironments (SHAPE) project". It does not belong to a conference.

Acknowledgements. This study was funded by Fondecyt nos. 1080485, 1121141 and 1151469; ICM grants P05-002 and NC120066; and a CONICYT MSc Scholarship to William I. Henríquez. We thank Esteban A. Sagredo, Oscar H. Pesce, Enzo Simi, and Ignacio Jara for assistance during field work and Keith D. Bennett and Simon Haberle for sharing published palynological data. We thank Cristian Saucedo from Agencia de Conservación Patagónica for permission to work and collect samples in Hacienda Valle Chacabuco (Parque Patagonia). We thank the editor and the three anonymous reviewers for their constructive comments on early versions of this paper.
Edited by: Helen Bostock

Reviewed by: three anonymous referees

\section{References}

Bennett, K. D. and Provan, J.: What do we mean by "refugia"?, Quaternary Sci. Rev., 27, 2449-2455, 2008.

Blaauw, M. and Christen, J. A.: Flexible Paleoclimate Age-Depth Models Using an Autoregressive Gamma Process, Bayesian Anal., 6, 457-474, 2011.

Boex, J., Fogwill, C., Harrison, S., Glasser, N. F., Hein, A., Schnabel, C., and Xu, S.: Rapid thinning of the late Pleistocene Patagonian Ice Sheet followed migration of the Southern Westerlies, Sci. Rep.-UK, 3, 2118, https://doi.org/10.1038/srep02118, 2013.

Bourgois, J., Cisternas, M. E., Braucher, R., Bourlès, D., and Frutos, J.: Geomorphic Records along the General Carrera (Chile)Buenos Aires (Argentina) Glacial Lake (46-48 $\left.{ }^{\circ} \mathrm{S}\right)$, Climate Inferences, and Glacial Rebound for the Past 7-9 ka, J. Geol., 124, 27-53, 2016.

Bromwich, D. H., Toracinta, E. R., Wei, H., Oglesby, R. J., Fastook, J. L., and Hughes, T. J.: Polar MM5 Simulations of the Winter Climate of the Laurentide Ice Sheet at the LGM, J. Climate, 17, 3415-3433, 2004.

Bromwich, D. H., Toracinta, E. R., Oglesby, R. J., Fastook, J. L., and Hughes, T. J.: LGM Summer Climate on the Southern Margin of the Laurentide Ice Sheet: Wet or Dry?, J. Climate, 18, 3317-3338, 2005.

Caniupán, M., Lamy, F., Lange, C. B., Kaiser, J., Arz, H., Kilian, R., Baeza Urrea, O., Aracena, C., Hebbeln, D., Kissel, C., Laj, C., Mollenhauer, G., and Tiedemann, R.: Millennial-scale sea surface temperature and Patagonian Ice Sheet changes off southernmost Chile $\left(53^{\circ} \mathrm{S}\right)$ over the past $\sim 60 \mathrm{kyr}$, Paleoceanography, 26 , PA3221, https://doi.org/10.1029/2010PA002049, 2011.

de Porras, M. E., Maldonado, A., Abarzúa, A. M., Cárdenas, M. L., Francois, J. P., Martel-Cea, A., Stern, C. R., Méndez, C., and Reyes, O.: Postglacial vegetation, fire and climate dynamics at Central Chilean Patagonia (Lake Shaman, $44^{\circ} \mathrm{S}$ ), Quaternary Sci. Rev., 50, 71-85, 2012.

Denton, G. H., Lowell, T. V., Heusser, C. J., Schluchter, C., Andersen, B. G., Heusser, L. E., Moreno, P. I., and Marchant, D. R.: Geomorphology, stratigraphy, and radiocarbon chronology of Llanquihue drift in the area of the southern Lake District, Seno Reloncavi, and Isla Grande de Chiloe, Chile, Geogr. Ann. A, 81, 167-229, 1999.

Faegri, K. and Iversen, J.: Textbook of pollen analysis, John Wiley \& Sons, 1989.

Fletcher, M. S. and Moreno, P. I.: Zonally symmetric changes in the strength and position of the Southern Westerlies drove atmospheric $\mathrm{CO}_{2}$ variations over the past $14 \mathrm{ky}$, Geology, 39, 419422, 2011.

Gajardo, R.: La Vegetación Natural de Chile, Clasificación y Distribución Geográfica, Editorial Universitaria, Santiago, Chile, 1994.

Garcia, J. L., Kaplan, M. R., Hall, B. L., Schaefer, J. M., Vega, R. M., Schwartz, R., and Finkel, R.: Glacier expansion in southern Patagonia throughout the Antarctic cold reversal, Geology, 40, 859-862, 2012. 
Garreaud, R., Lopez, P., Minvielle, M., and Rojas, M.: Large-Scale Control on the Patagonian Climate, J. Climate, 26, 215-230, 2013.

Glasser, N. F., Harrison, S., Schnabel, C., Fabel, D., and Jansson, K. N.: Younger Dryas and early Holocene age glacier advances in Patagonia, Quaternary Sci. Rev., 58, 7-17, 2012.

Glasser, N. F., Jansson, K. N., Duller, G. A. T., Singarayer, J., Holloway, M., and Harrison, S.: Glacial lake drainage in Patagonia (13-8 kyr) and response of the adjacent Pacific Ocean, Sci. Rep.UK, 6, 21064, https://doi.org/10.1038/srep21064, 2016.

Haberle, S. G. and Bennett, K. D.: Postglacial formation and dynamics of North Patagonian Rainforest in the Chonos Archipelago, Southern Chile, Quaternary Sci. Rev., 23, 24332452, 2004.

Hall, B. L., Porter, C. T., Denton, G. H., Lowell, T. V., and Bromley, G. R. M.: Extensive recession of Cordillera Darwin glaciers in southernmost South America during Heinrich Stadial 1, Quaternary Sci. Rev., 62, 49-55, 2013.

Hein, A. S., Hulton, N. R. J., Dunai, T. J., Sugden, D. E., Kaplan, M. R., and Xu, S.: The chronology of the Last Glacial Maximum and deglacial events in central Argentine Patagonia, Quaternary Sci. Rev., 29, 1212-1227, 2010.

Heiri, O., Lotter, A. F., and Lemcke, G.: Loss on ignition as a method for estimating organic and carbonate content in sediments: reproducibility and comparability of results, J. Paleolimnol., 25, 101-110, 2001.

Heusser, C. J.: Pollen and Spores from Chile, University of Arizona Press, Tucson, 1971.

Heusser, C. J.: Late Quaternary Vegetation and Climate of Southern Tierra-Del-Fuego, Quaternary Res., 31, 396-406, 1989.

Higuera, P. E., Brubaker, L. B., Anderson, P. M., Hu, F. S., and Brown, T. A.: Vegetation mediated the impacts of postglacial climate change on fire regimes in the south-central Brooks Range, Alaska, Ecol. Monogr., 79, 201-219, 2009.

Kaplan, M. R., Schaefer, J. M., Denton, G. H., Barrell, D. J. A., Chinn, T. J. H., Putnam, A. E., Andersen, B. G., Finkel, R. C., Schwartz, R., and Doughty, A. M.: Glacier retreat in New Zealand during the Younger Dryas stadial, Nature, 467, 194-197, 2010.

Kaplan, M. R., Strelin, J. A., Schaefer, J. M., Denton, G. H., Finkel, R. C., Schwartz, R., Putnam, A. E., Vandergoes, M. J., Goehring, B. M., and Travis, S. G.: In-situ cosmogenic ${ }^{10}$ Be production rate at Lago Argentino, Patagonia: Implications for late-glacial climate chronology, Earth Planet Sc. Lett., 309, 21-32, 2011.

Kaufman, D. S., Ager, T. A., Anderson, N. J., Anderson, P. M., Andrews, J. T., Bartlein, P. J., Brubaker, L. B., Coats, L. L., Cwynar, L. C., Duvall, M. L., Dyke, A. S., Edwards, M. E., Eisner, W. R., Gajewski, K., Geirsdottir, A., Hu, F. S., Jennings, A. E., Kaplan, M. R., Kerwin, M. N., Lozhkin, A. V., MacDonald, G. M., Miller, G. H., Mock, C. J., Oswald, W. W., Otto-Bliesner, B. L., Porinchu, D. F., Ruhland, K., Smol, J. P., Steig, E. J., and Wolfe, B. B.: Holocene thermal maximum in the western Arctic (0-180 W), Quaternary Sci. Rev., 23, 529-560, 2004.

Lara, A., Villalba, R., Wolodarsky-Franke, A., Aravena, J. C., Luckman, B. H., and Cuq, E.: Spatial and temporal variation in Nothofagus pumilio growth at tree line along its latitudinal range ( 35 degrees 40'-55 degrees $\mathrm{S}$ ) in the Chilean Andes, J. Biogeogr., 32, 879-893, 2005.
Luebert, F. and Pliscoff, P.: Sinopsis Bioclimática y Vegetacional de Chile, Editorial Universitaria, Santiago, Chile, 2006.

Lumley, S. and Switsur, R.: Late Quaternary chronology of the Taitao Peninsula, Southern Chile, J. Quaternary Sci., 8, 161-165, 1993.

Mancini, M. V.: Vegetation and climate during the holocene in Southwest Patagonia, Argentina, Rev. Palaeobot. Palyno., 122, 101-115, 2002.

Markgraf, V., Whitlock, C., and Haberle, S.: Vegetation and fire history during the last 18,000 cal yr BP in Southern Patagonia: Mallin Pollux, Coyhaique, Province Aisen (45 degrees 41'30" S, 71 degrees $50^{\prime} 30^{\prime \prime} \mathrm{W}, 640 \mathrm{~m}$ elevation), Palaeogeogr. Palaeocl., 254, 492-507, 2007.

Moreno, P. I., Kaplan, M. R., Francois, J. P., Villa-Martinez, R., Moy, C. M., Stern, C. R., and Kubik, P. W.: Renewed glacial activity during the Antarctic cold reversal and persistence of cold conditions until 11.5 ka in southwestern Patagonia, Geology, 37, 375-378, 2009.

Moreno, P. I., Francois, J. P., Villa-Martínez, R., and Moy, C. M.: Covariability of the Southern Westerlies and atmospheric $\mathrm{CO}_{2}$ during the Holocene, Geology, 39, 727-730, 2010.

Moreno, P. I., Villa-Martinez, R., Cardenas, M. L., and Sagredo, E. A.: Deglacial changes of the southern margin of the southern westerly winds revealed by terrestrial records from SW Patagonia (52 degrees S), Quaternary Sci. Rev., 41, 1-21, 2012.

Moreno, P. I., Vilanova, I., Villa-Martínez, R., Garreaud, R. D., Rojas, M., and De Pol-Holz, R.: Southern Annular Mode-like changes in southwestern Patagonia at centennial timescales over the last three millennia, Nat. Commun., 5, 4375, https://doi.org/10.1038/ncomms5375, 2014.

Moreno, P. I., Denton, G. H., Moreno, H., Lowell, T. V., Putnam, A. E., and Kaplan, M. R.: Radiocarbon chronology of the last glacial maximum and its termination in northwestern Patagonia, Quaternary Sci. Rev., 122, 233-249, 2015.

Pesce, O. H. and Moreno, P. I.: Vegetation, fire and climate change in central-east Isla Grande de Chiloé $\left(43^{\circ} \mathrm{S}\right)$ since the Last Glacial Maximum, northwestern Patagonia, Quaternary Sci. Rev., 90, 143-157, 2014.

Pisano, E.: Los bosques de Patagonia Austral y Tierra del Fuego chilenas, Anales del Instituto de la Patagonia - Serie Ciencias Naturales (Chile), 25, 9-19, 1997.

Putnam, A. E., Denton, G. H., Schaefer, J. M., Barrell, D. J. A., Andersen, B. G., Finkel, R. C., Schwartz, R., Doughty, A. M., Kaplan, M. R., and Schluchter, C.: Glacier advance in southern middle-latitudes during the Antarctic Cold Reversal, Nat. Geosci., 3, 700-704, 2010.

Schmithüsen, J.: Die raumliche Ordnung der chilenischen Vegetation, Bonner Geographische Abhandlungen, 17, 1-86, 1956.

Siani, G., Michel, E., De Pol-Holz, R., DeVries, T., Lamy, F., Carel, M., Isguder, G., Dewilde, F., and Lourantou, A.: Carbon isotope records reveal precise timing of enhanced Southern Ocean upwelling during the last deglaciation, Nat. Commun., 4, 2758, 2013.

Stenni, B., Masson-Delmotte, V., Selmo, E., Oerter, H., Meyer, H., Rothlisberger, R., Jouzel, J., Cattani, O., Falourd, S., Fischer, H., Hoffmann, G., Iacumin, P., Johnsen, S. J., Minster, B., and Udisti, R.: The deuterium excess records of EPICA Dome $\mathrm{C}$ and Dronning Maud Land ice cores (East Antarctica), Quaternary Sci. Rev., 29, 146-159, 2010. 
Stern, C.: Active Andean volcanism: its geologic and tectonic setting, Rev. Geol. Chile, 31, 161-206, 2004.

Stern, C. R., Moreno, P. I., Henriquez, W. I., Villa-Martinez, R., Sagredo, E., Aravena, J. C., and De Pol-Holz, R.: Holocene tephrochronology around Cochrane $\left(\sim 47^{\circ} \mathrm{S}\right)$, southern Chile, Andean Geol., 43, 1-19, 2016.

Strelin, J. A. and Malagnino, E. C.:Late-Glacial History of Lago Argentino, Argentina, and Age of the Puerto Bandera Moraines, Quaternary Res., 54, 339-347, 2000.

Strelin, J. A., Denton, G. H., Vandergoes, M. J., Ninnemann, U. S., and Putnam, A. E.: Radiocarbon chronology of the lateglacial Puerto Bandera moraines, Southern Patagonian Icefield, Argentina, Quaternary Sci. Rev., 30, 2551-2569, 2011.
Sugita, S.: Pollen Representation of Vegetation in Quaternary Sediments: Theory and Method in Patchy Vegetation, J. Ecology, 82, 881-897, 1994.

Turner, K. J., Fogwill, C. J., McCulloch, R. D., and Sugden, D. E.: Deglaciation of the eastern flank of the North Patagonian Icefield and associated continental-scale lake diversions, Geogr. Ann. A, 87, 363-374, 2005.

Villa-Martinez, R., Moreno, P. I., and Valenzuela, M. A.: Deglacial and postglacial vegetation changes on the eastern slopes of the central Patagonian Andes (47 degrees S), Quaternary Sci. Rev., 32, 86-99, 2012. 